\title{
Grain Refinement in Al-Mn-Fe-Si Alloys by Severe Plastic Deformation
}

Michaela Šlapáková Poková, Miroslav Cieslar, Mariia Zimina

Charles University in Prague, Faculty of Mathematics and Physics, Department of Physics of Materials

Ke Karlovu 5, 12116 Prague 2, Czech Republic, E-mail: pokova@karlov.mff.cuni.cz, cieslar@met.cuni.cz, m.zimina@seznam.cz

\begin{abstract}
Aluminium alloys are widely used materials and their properties are constantly being improved. The enhanced properties can be achieved, for instance by alternation of chemical composition or processing route. Severe plastic deformation leads to an increase of strength due to a grain size reduction. Two Al-Mn-Fe-Si alloys differing in $\mathrm{Zr}$ content were subjected to four passes of equal channel angular pressing. Grain size was re-duced from $100 \mu \mathrm{m}$ to $0.5 \mu \mathrm{m}$. In the course of subsequent annealing to $400 \circ \mathrm{C}$ the grain size rose moderate-ly; at $450{ }^{\circ} \mathrm{C}$ both materials recrystallized and new defect free grains were formed; with fraction of high angle grain boundaries nearly 1 . The recrystallized grain size was comparable with the grain size after cast-ing. Moreover, high density of $\alpha$ $\mathrm{Al}(\mathrm{Mn}, \mathrm{Fe}) \mathrm{Si}$ particles precipitated during annealing in both alloys.
\end{abstract}

Keywords: Aluminium alloys, Twin-roll casting, Equal-channel angular pressing, Scanning electron microscopy, Electron back-scatter diffraction

\section{Acknowledgement}

The financial support of grant GAČR P107-12-0921 is gratefully acknowledged.

\section{References}

[1] M. M. R. JARADEH, T. CARLBERG (2011). Solidification studies of 3003 aluminium alloys with $\mathrm{Cu}$ and $\mathrm{Zr}$ additions. In: Journal of Materials Science \& Technology, Vol. 27, pp. 615-627.

[2] F. KHAKBAZ, M. KAZEMINEZHAD (2012). Work hardening and mechanical properties of severely deformed AA3003 by constrained groove pressing. In: Journal of Manufacturing Processes, Vol. 14, pp. 20-25.

[3] M. YUN, S. LOKYER, J. D. HUNT (2000). Twin roll casting of aluminium alloys. In: Materials Science and Engineering A, Vol. 280, pp. 116-123.

[4] M. SLÁMOVÁ, M. KARLÍK, M. CIESLAR, B. CHALUPA, P. MERLE (2002). Structure Transfor-mation during Annealing of Twin-roll Cast Al-Fe-Mn-Si (AA8006) Alloy Sheets I. Effect of Cold Rolling and Heating Rate. In: Kovové Materiály, Vol. 40, pp. 389-400.

[5] Y. BIROL (2009). Homogenization of a twin-roll cast thin Al-Mn strip. In: Journal of Alloys and Compounds, Vol. 471, pp. 122-127.

[6] C. GRAS, M. MEREDITH, J. D. HUNT (2005). Microstructure and texture evolution after twin roll casting and subsequent cold rolling of Al-Mg-Mn aluminium alloys. In: Journal of Materials Processing Technology, Vol. 169 , pp. 156-16.

[7] Y. IWAHASHI, Z. HORITA, M. NEMOTO, T. G. LANGDON (1997). An Investigation of Micro-structual Evolution during Equal-Channel Angular Pressing. Acta Materialia, Vol. 45, pp. 4733-474.

[8] M. POKOVÁ, M. CIESLAR (2014). Study of Twin-roll Cast Aluminium Alloys Subjected to Se-vere Plastic Deformation by Equal Channel Angular Pressing. In: Materials Science and Engineering, IOP Conference Series, Vol. 63, pp. 012086.

[9] M. POKOVÁ, M. CIESLAR (2014). Microstructure Evolution of Al-Mn-Si-Fe Alloy Studied by Insitu Transmission Electron Microscopy. In: Manufacturing Technology, Vol. 14, pp. 412-417.

[10]M. POKOVÁ, M. ZIMINA, M. CIESLAR (2015). The Evolution of Microstructure and Mechan-ical Properties of Al-Mn-Fe-Si Alloys during Isothermal Annealing. In: Acta Physica Polonica, Vol. 128, in press.

[11]M. CIESLAR, M. POKOVÁ (2014). Annealing Effects in Twin-Roll Cast AA8006 Aluminium Sheets Processed by Accumulative Roll-Bonding. In: Materials, Vol. 7, pp. 8058-8069.

[12]V. M. SEGAL (1995). Materials processing by simple shear. In: Materials Science and Engineering A, Vol. 197, pp. 157-164.

[13]K. TURBA, P. MÁLEK, M. CIESLAR (2007). Superplasticity in a Zr and Sc Modified AA7075 Aluminium Alloy Produced by ECAP. In: Kovové Materiály, Vol. 45, pp. 165-170. 
[14]J. L. NING, D. M. JIANG (2007). Influence of Zr addition on the microstructure evolution and thermal stability of Al-Mg-Mn alloy processed by ECAP at elevated temperature. In: Materials Scence and Engineering A, Vol. 452-453, pp. 552-557.

[15]D. JIANG, J. NING, J. SUN, Z. HU, Y. HOU (2008). Annealing Behavior of Al-Mg-Mn Alloy Processed by ECAP at Elevated Temperature. In: Transaction of Nonferrous Metals Society of China, Vol. 18, pp. 248-254.

[16]H. G. KANG, J. P. LEE, M. Y. HUH, O. ENGLER (2008). Stability against coarsening in ul-tra-fine grained aluminum alloy AA3103 sheet fabricated by continuous confined strip sheering. In: Materials Science and Engneering A, Vol. 486, pp. 470-480.

[17]M. POKOVÁ, M. CIESLAR, J. LACAZE (2012). The Influence of Pre-deformation on Minority Phases Precipitation in Modified AW-3003 Aluminium. In: Metal 2012 Conference Proceedings, Brno, pp. 1149-1155.

[18]M. POKOVÁ, M. ZIMINA, M. CIESLAR, O. GRYDIN (2015). Investigation of asymmetric rolling applied to twin-roll cast Al-Mn alloy. In: Metal 2015 Conference Proceedings, Brno, p. 3816.

[19]P. MÁLEK, M. POKOVÁ, M. CIESLAR (2014). The Influence of ECAP on Mechanical Proper-ties of a Twinroll Cast Al-Mn-Fe-Si-Zr Alloy. In: Metal 2014 Conference Proceedings, Brno, pp. 247-252.

[20]M. POKOVÁ, M. ZIMINA, M. CIESLAR (2015). The Influence of Equal Channel Angular Pressing on Microstructure Evolution during In-situ Heating in Transmission Electron Micro-scope. In: International Journal of Materials Research, Vol. 106, pp. 676-681.

[21]G. GOTTSTEIN, L. S. SHVINDLERMAN (2010). Grain Boundary Migration in Metals, New York: CRC Press. 